Louisiana State University

LSU Digital Commons

$5-1-2009$

\title{
Arc-continent collision and the formation of continental crust: A new geochemical and isotopic record from the Ordovician Tyrone Igneous Complex, Ireland
}

\author{
Amy E. Draut \\ United States Geological Survey Western Region \\ Peter D. Clift \\ University of Aberdeen \\ Jeffrey M. Amato \\ New Mexico State University \\ Jerzy Blusztajn \\ Woods Hole Oceanographic Institution \\ Hans Schouten \\ Woods Hole Oceanographic Institution
}

Follow this and additional works at: https://digitalcommons.Isu.edu/geo_pubs

\section{Recommended Citation}

Draut, A., Clift, P., Amato, J., Blusztajn, J., \& Schouten, H. (2009). Arc-continent collision and the formation of continental crust: A new geochemical and isotopic record from the Ordovician Tyrone Igneous Complex, Ireland. Journal of the Geological Society, 166 (3), 485-500. https://doi.org/10.1144/ 0016-76492008-102

This Article is brought to you for free and open access by the Department of Geology and Geophysics at LSU Digital Commons. It has been accepted for inclusion in Faculty Publications by an authorized administrator of LSU Digital Commons. For more information, please contact ir@lsu.edu. 


\title{
Arc-Continent Collision and the Formation of Continental Crust: A New Geochemical and Isotopic Record from the Ordovician Tyrone Igneous Complex, Ireland
}

\author{
Amy E. Draut \\ U.S. Geological Survey, Santa Cruz, CA 95060, U.S.A. adraut@usgs.gov \\ Peter D. Clift \\ School of Geosciences, University of Aberdeen, Aberdeen AB24 3UE, United Kingdom \\ Jeffrey M. Amato \\ Department of Geological Sciences, New Mexico State University, Las Cruces, NM \\ 88003, U.S.A. \\ Jerzy Blusztajn and Hans Schouten \\ Department of Geology and Geophysics, Woods Hole Oceanographic Institution, Woods \\ Hole, MA 02543, U.S.A.
}

\begin{abstract}
Collisions between oceanic island-arc terranes and passive continental margins are thought to have been important in the formation of continental crust throughout much of Earth's history. Magmatic evolution during this stage of the plate-tectonic cycle is evident in several areas of the Ordovician Grampian-Taconic Orogen, as we demonstrate in the first detailed geochemical study of the Tyrone Igneous Complex, Ireland. New U$\mathrm{Pb}$ zircon dating yields ages of $493 \pm 2$ Ma from a primitive mafic intrusion, indicating intra-oceanic subduction in Tremadoc time, and $475 \pm 10$ Ma from a light-rare-earthelement (LREE)-enriched tonalite intrusion that incorporated Laurentian continental material by early Arenig time (Early Ordovician, Stage 2) during arc-continent collision. Notably, LREE enrichment in volcanism and silicic intrusions of the Tyrone Igneous
\end{abstract}


Complex exceeds that of average Dalradian (Laurentian) continental material which would have been thrust under the colliding forearc and potentially recycled into arc magmatism. This implies that crystal fractionation, in addition to magmatic mixing and assimilation, was important to the formation of new crust in the Grampian-Taconic Orogeny. Because similar super-enrichment of orogenic melts occurred elsewhere in the Caledonides in the British Isles and Newfoundland, the addition of new, highly enriched melt to this accreted arc terrane was apparently widespread spatially and temporally. Such super-enrichment of magmatism, especially if accompanied by loss of corresponding lower crustal residues, supports the theory that arc-continent collision plays an important role in altering bulk crustal composition toward typical values for ancient continental crust.

Keywords: subduction, continental crust, arc-continent collision, Caledonides, Ireland

The processes responsible for the formation and maintenance of the continental crust are complex and continue to be debated by Earth scientists. Although $>40 \%$ of extant cratonal crust formed in Archean time (e.g., Rudnick \& Fountain 1995; Hawkesworth \& Kemp 2006), additional growth has occurred through accretion of oceanic arcs, plateaus, and microcontinental terranes, and by continental flood volcanism. Mass balancing suggests that arc accretion is essential to compensate for the ongoing loss of continental crust in subduction zones (Clift \& Vannucchi 2004). Shared trace-element characteristics between intra-oceanic arc volcanism and continental material-relative depletion in high-field-strength elements (HFSEs), such as Nb, relative to light-rare-earth elements (LREE), $\mathrm{K}$, and $\mathrm{Ba}$-imply that continental material could form at convergent margins (e.g., Davidson 1996). However, the concept of island arcs being the building blocks of continents is not easily reconciled with the mafic, LREE-depleted composition of known oceanic arc crust compared to the andesitic, LREE-enriched continental crust (Taylor 1967; Bryan et al. 1972; Taylor \& McLennan 1985; Ellam \& Hawkesworth 1988; Rudnick \& Fountain 1995). Seismic-velocity profiles and field studies of the active 
Aleutian arc (Holbrook et al. 1999) and ancient, accreted arc terranes in Kohistan (Miller \& Christensen 1994) and Alaska (DeBari \& Coleman 1989; Kelemen et al. 2003) reveal dominantly mafic and ultramafic arc crust inconsistent with development of average continental-type material; one notable exception is the observation of low-velocity, siliceous mid-crustal material in the Izu-Bonin Arc by Suyehiro et al. (1996). Pearcy et al. (1990) and Holbrook et al. (1999) proposed a resolution to this paradox: the process of arc-continent collision might alter the composition of arc crust such that the accreted crust is more LREE-enriched and andesitic than the arc crust before accretion. Based on the Early Ordovician accretion of an oceanic island arc onto the Laurentian continent as preserved in the Grampian Orogen of western Ireland (Connemara and South Mayo terranes; Fig. 1), Draut et al. (2002) showed that crystal fractionation producing LREEenriched, silica-rich melts, coupled with lower crustal loss after orogeny, could drive magmatic compositions toward that of average continental crust. Here, we revisit and expand that finding further to the northeast in the Caledonide suture zone. We document more fully the magmatic evolution that occurred during this arc-continent collision, and in doing so, we present the first detailed petrologic and geochemical study of the Tyrone Igneous Complex, Ireland.

\section{Geological Setting}

Early Ordovician collision of an intra-oceanic island arc with the Laurentian passive continental margin was the first substantial orogenic event to occur as the Iapetus Ocean closed (van Staal et al. 1998, 2007). This event, which significantly pre-dates final closure of the Iapetus Ocean at $\sim 400 \mathrm{Ma}$, is known as the Grampian Orogeny in the British Isles, where it formed part of the Caledonide suture zone, and as the Taconic Orogeny in its continuation in North America (northern Appalachian suture; e.g. Swinden et al. 1997; van Staal et al. 1998). Before collision, the intra-oceanic subduction zone involved a north-facing arc that formed above a south-dipping slab (Dewey \& Ryan 1990). This oceanic arc is known variously as the Lough Nafooey arc in Ireland (Clift \& Ryan 1994; Draut \& Clift 2001), the buried Midland Valley arc in Scotland (Armstrong \& Owen 2001; Oliver et al. 2008), and the Shelburne Falls arc in New England (Karabinos et al. 1998), and is thought to correlate with the Baie Verte Oceanic Tract and 
overlying Snooks Arm Group in Newfoundland (van Staal et al. 2007). In Newfoundland exposures, there is evidence that this arc, at least in that part of the margin, was built upon a microcontinent (Dashwoods block) that had rifted away from Laurentia in Cambrian time and was re-accreted onto the continent as the Grampian Orogeny progressed (Waldron \& van Staal 2001).

A reversal of subduction polarity followed arc-continent collision, with the new subducting plate dipping to the north beneath the active Laurentian margin (e.g. McKerrow et al. 1991). Although the post-collisional (continental) arc is not well exposed in Ireland, elsewhere in the Caledonide suture it is recognized as the Bronson Hill arc of New England (Karabinos et al. 1998), as the younger units of the Notre Dame terrane of Newfoundland (van Staal et al. 1998, 2007), and as related to the Southern Uplands accretionary prism in Scotland (Armstrong \& Owen 2001).

$\mathrm{U}-\mathrm{Pb}$ analyses of zircon from syn-collisional gabbro intrusions in Connemara (Fig. 1; Cliff et al. 1996; Friedrich et al. 1999), and from tonalite and granitoid bodies in the Slishwood Division (Flowerdew et al. 2005), together with trace-element analyses of volcanic rocks from South Mayo in western Ireland (Draut \& Clift 2001), indicate that the arc-continent collision event was brief in the British Isles, lasting approximately 10 My ( 475 to $465 \mathrm{Ma}$ ). Nd isotopic ratios of plagiogranite clasts from South Mayo imply that continental material started to enter the trench as early as ca. $490 \mathrm{Ma}$, substantially earlier than regional metamorphism and orogeny (Chew et al. 2007). Other age constraints on the Grampian Orogeny in Ireland include mineral cooling ages from Connemara (Friedrich et al. 1999) and the Slishwood Division (Flowerdew et al. 2000; Fig. 1), which indicated rapid orogenic exhumation after ca. $460 \mathrm{Ma}$, and detailed graptolite biostratigraphy from pre-, syn-, and post-collisional volcaniclastic rocks in South Mayo (Graham et al. 1989); see Dewey \& Mange (1999) for a detailed discussion of stratigraphic age correlation in Grampian units of South Mayo and Connemara.

The Tyrone Igneous Complex (TIC), covering $\sim 350 \mathrm{~km}^{2}$ of Counties Tyrone and Londonderry, Northern Ireland, was described by Hartley (1933) as consisting of a dominantly mafic plutonic complex with younger silicic intrusions (Stillman 1981; Tyrone Plutonic Group of Cooper et al. 2008) that Hutton et al. (1985) identified as an ophiolite related to the Ballantrae ophiolite in SW Scotland (Bluck 1985), and a silicic 
volcanic sequence (Tyrone Volcanic Group of Cooper et al. 2008). Structurally below both groups is the high-grade metasedimentary Tyrone Central Inlier. The lithology of the Tyrone Central Inlier suggested possible correlation with Dalradian (Laurentian passive margin) units from which it could have been offset by post-Grampian strike-slip faulting (cf. Dewey \& Shackleton 1984). Structural, thermochronological, and detritalzircon analyses led Chew et al. (2008) to interpret the Tyrone Central Inlier as a microcontinental block with which the Lough Nafooey arc collided ca. $475 \mathrm{Ma}$, before accretion of the amalgamated arc/microcontinent onto Laurentia proper as the Grampian Orogeny progressed (cf. Dashwoods microcontinent of Waldron \& van Staal 2001; van Staal et al. 2007). The entire TIC is bounded to the northwest by a 10-km-thick ductile shear zone along the NE-trending Omagh Thrust, which emplaced Dalradian rocks over the TIC during the Caledonide Orogeny and which was reactivated during Late Paleozoic time (Alsop \& Hutton 1993; Figs. 1, 2).

The TIC was assigned an Arenig-Llanvirn age (478-461; we use the traditional stage names of Tucker \& McKerrow (1995) although some of those do not appear on the more recent geologic time scale by Gradstein et al. (2004), whose stage-boundary ages we use) based on a graptolite specimen from shales interbedded with the volcanic sequence, first analyzed by Hartley (1936) and reinterpreted by Hutton and Holland (1992). The mafic assemblage of the TIC is intruded by a siliceous pluton near Craigballyharky (Fig. 1) from which Hutton et al. (1985) obtained an Arenig U-Pb zircon age of $471+2 /-4$ Ma. Cooper et al. (2008) acquired a U-Pb zircon age of $473 \pm$ 0.8 Ma from a rhyolite exposure within the Tyrone Volcanic Group, and further refined a biostratigraphic age by identifying Arenig (Whitlandian) graptolite specimens in the northeastern exposures of the volcanic assemblage.

Despite several detailed structural and age-determining studies, the geochemistry of the TIC has remained largely unknown. Here, we present major- and trace-element analyses, and Nd isotopic data, from rocks of the Tyrone Plutonic Group, the Tyrone Volcanic Group, and from igneous intrusions within them, as well as two new $\mathrm{U}-\mathrm{Pb}$ zircon ages. These new data constrain the tectonic setting of the magmatism and trace the magmatic evolution corresponding to significant tectonic events in the early history of Iapetus Ocean closure. We demonstrate that the TIC corresponds to the arc units exposed 
in Connemara and South Mayo, along the strike of the Grampian suture zone. By comparing the geochemical progression during arc-continent collision as recorded in the TIC with that of other Caledonide exposures in the British Isles and North America, we assess on a regional basis whether magmatism accompanying this terrane accretion could drive the bulk composition of accreted arc crust toward that of average continental crust, thereby testing a subduction-zone origin for the formation of continents.

\section{Sampling and Analytical Methods}

Rock samples were collected from the TIC at sites shown on Figure 1 and specified in Table 1. Localities sampled within the Tyrone Plutonic Group include outcrops near Craigballyharky, an active quarry near Carrickmore, and outcrops on a hill known as the Scalp. Sample localities within the Tyrone Volcanic Group include outcrops near Lougham Crory, Leaghan, east and southeast of Greencastle, in the Sperrin Mountains east of the Omagh Thrust, and three quarries sampled in and around Mountfield. In this initial survey we sampled a variety of lithologies at different stratigraphic levels in the TIC to evaluate the diversity of compositions erupted at different stages in the generation of the igneous complex. More detailed sampling of limited regions may be appropriate in future focused studies.

\section{Geochemical and Nd Isotopic Analyses}

The major-element content of 34 powdered whole-rock samples was determined by X-ray fluorescence (XRF) using a Philips PW2404 automatic X-ray spectrometer at the University of Edinburgh. XRF techniques, and analytical accuracy and precision, were essentially those described by Fitton et al. (1998) with modifications noted by Fitton \& Godard (2004). Trace-element composition was determined for the same 34 whole-rock samples by inductively coupled plasma mass spectrometry (ICP-MS) at Washington State University. U.S. Geological Survey standard BCR-1 was used to determine internal and external precision of the ICP-MS analyses. Uncertainty, determined from duplicate analyses of samples and standards, is $<3 \%$ for REEs and $<5 \%$ for other elements. 
A subset of 11 samples were selected for $\mathrm{Nd}$ isotopic analysis using a Neptune multi-collector ICP-MS at the Woods Hole Oceanographic Institution. The precision of Nd data is better than $0.002 \%$. Reproducibility is better than $0.003 \%$ based on multiple analyses of a La Jolla standard. An age correction (DePaolo \& Wasserburg 1976) was performed to account for radioactive decay of ${ }^{147} \mathrm{Sm}$ to ${ }^{143} \mathrm{Nd}$ since eruption, taken to be $470 \mathrm{Ma}$; values for that time are reported as $\boldsymbol{\varepsilon}_{\mathrm{Nd}(\mathrm{t})}$.

\section{U-Pb Geochronology}

Two additional rock samples were collected from which zircon grains were separated for $\mathrm{U}-\mathrm{Pb}$ dating. One was a gabbro sample from the Craigballyharky area (sample TY07043003, from the same outcrop as samples TY07043001 and TY07043002, which were analyzed for geochemistry and Nd isotopes; Table 1). The other was a tonalite sample collected near Leaghan (sample TY07050204, from the same outcrop as sample TY07050115, which was analyzed for geochemistry and Nd isotopes; Table 1).

$\mathrm{U}-\mathrm{Pb}$ dating was conducted using SHRIMP-RG (sensitive high-resolution ion microprobe, reverse geometry) at the U.S. Geological Survey-Stanford University Ion Probe Facility. Approximately $10 \mathrm{~kg}$ of sample were crushed using a jaw crusher and disc grinder and processed for mineral separations using a Gemeni water table. Zircon grains were concentrated using methylene iodide (MEI) and a Frantz magnetic separator. Zircons were hand-picked from material that sank in MEI and was non-magnetic at 1.8 A. Errors on spot ages of individual zircons grains are reported at $1 \sigma$, and weighted mean ages were calculated and reported at the $2 \sigma$ level. About 30-50 zircons were put on 2.5 cm epoxy mounts for individual analysis. A 30- $\mu \mathrm{m}$ diameter, 8-12 nA O2 primary beam was used to sputter the zircon grains for analysis, following 90 seconds of rastering to remove potential surface contamination. $\mathrm{U}, \mathrm{Th}$, and $\mathrm{Pb}$ concentrations were standardized against RG-6 zircons that were analyzed after every four unknown analyses. Data were reduced using the SQUID program (Ludwig 2001). Decay constants of Steiger \& Jäger (1977) were used for all $\mathrm{U}-\mathrm{Pb}$ dating. $\mathrm{Pb} / \mathrm{U}$ ratios were corrected for common $\mathrm{Pb}$ using

${ }^{204} \mathrm{~Pb}$ and the model $\mathrm{Pb}$ evolution curve of Stacey \& Kramers (1975). Weighted mean U$\mathrm{Pb}$ ages and Concordia plots were derived using Isoplot (Ludwig 2003). LA-MC-ICPMS 
(laser ablation, multi-collector, inductively coupled plasma mass-spectrometry) dating of inherited zircons was conducted at the University of Arizona LaserChron laboratory. A $35-\mu \mathrm{m}$ diameter beam was used. Further details of LA-MC-ICPMS dating techniques can be found in Gehrels et al. (2008).

\section{Results}

\section{Geochemical and Nd Isotopic Analyses}

Chemical compositions in the Tyrone Plutonic Group rocks indicate a dominantly mafic host rock intruded by multiple siliceous plutons and associated dykes. Silicic intrusions were observed in outcrop at the Craigballyharky and Scalp localities; granite sampled at Craigballyharky was the same intrusion as the "tonalite" from which Hutton et al. (1985) obtained a $\mathrm{U}-\mathrm{Pb}$ intrusion age of $471+2 /-4 \mathrm{Ma}$. At the active quarry in Carrickmore, the same locality where Hutton et al. (1985) described an ophiolite sheeted dyke complex, fresh gabbro and basalt, including well exposed dykes, were abundant in the quarry walls exposed in 2007. However, the unequivocal sheeted-dyke characteristics described by Hutton et al. were not observed. Mafic samples from all three localities in the Tyrone Plutonic Group are tholeiitic (with exception of one alkali gabbro at Carrickmore; Fig. 3) with trace-element compositions characteristic of island-arc tholeiite (Pearce \& Cann 1973; Fig. 4). Mafic samples of the Tyrone Plutonic Group are generally LREE-depleted (Fig. 5), relatively depleted in HFSEs (e.g., Nb, Zr), and enriched in $\mathrm{Pb}$ (Fig. 6), consistent with a supra-subduction-zone origin. LREE enrichment in some mafic samples from Craigballyharky may have been caused by small veins from the adjacent granitic intrusion having been present in the sampled rocks.

$\varepsilon_{\mathrm{Nd}(t)}$ values for Carrickmore quarry samples are typical of oceanic petrogenesis, at +5.9 and +7.2 for dolerite and gabbro samples, respectively. Similarly, gabbro sampled at the Scalp gave an $\varepsilon_{\mathrm{Nd}(t)}$ value of +4.5 . At Craigballyharky, a more continental $\varepsilon_{\mathrm{Nd}(t)}$ value of -5.9 from a gabbro may have been influenced (as mentioned above) by inadvertently sampled veins from the granitic intrusion that has a strong continental 
signature $\left(\varepsilon_{\mathrm{Nd}(\mathrm{t})}-12.2\right.$; sample TY07043004 in Table 1). Intermediate and felsic samples from the Tyrone Plutonic Group show pronounced geochemical differences from the mafic rocks into which they intruded — granite and tonalite samples from Craigballyharky and the Scalp are enriched in LREE and other incompatible trace elements, while still showing HFSE depletion and $\mathrm{Pb}$ enrichment. Plotted on the granite discrimination diagram of Pearce et al. (1984), granitic samples from Craigballyharky indicate a syncollisional affinity, while other samples generally fall within the volcanic-arc field (Fig. 7).

The Tyrone Volcanic Group, exposed north of the Tyrone Plutonic Group and Tyrone Central Inlier, shows a broader range of major-element composition than do the plutonic rocks. All Tyrone Volcanic Group samples are LREE-enriched (Fig. 5), and all samples except those from the Mountfield quarries exhibit subduction-zone HFSE depletion and $\mathrm{Pb}$ enrichment (Fig. 6). Several samples gave relatively continental Nd isotopic signatures: $\varepsilon_{\mathrm{Nd}(\mathrm{t})}$ of -9.2 in a diorite SE of Greencastle, and -8.9 to -11.5 in tonalite and rhyolite near Leaghan (Table 1). However, calc-alkaline pillow basalts near Lougham Crory had a more oceanic $\varepsilon_{\mathrm{Nd}(t)}$ signature of +2.4 . Mafic volcanic rocks sampled near Mountfield, stratigraphically close to the top of the section (Cooper et al. 2008) and just below the Omagh Thrust, are generally alkaline (Fig. 3), show a lesser degree of LREE enrichment than other Tyrone Volcanic Group rocks, and show no HFSE depletion that would characterise supra-subduction-zone magmatism (Fig. 6). Mountfield rocks have trace-element signatures more similar to within-plate magmatism than to volcanic arcs according to the scheme of Pearce \& Cann (1973; Figs. 4 and 7). The $\boldsymbol{\varepsilon}_{\mathrm{Nd}(t)}$ value of a basalt sample from one Mountfield quarry was +1.3 .

\section{$U-P b$ Geochronology}

Eight zircon grains were analyzed from a gabbro sample (Table 2) collected at Craigballyharky within the Tyrone Plutonic Group, the host rock into which granitic melt intruded at ca. $471 \mathrm{Ma}$ (Hutton et al. 1985). Zircon grains had very high U concentrations (852-8090 ppm). The grain with 8090 ppm U and ca. 5\% Th was reversely discordant 
and was not used in the age calculation as extremely high-U zircons typically yield unreliable ages using SHRIMP. The weighted mean ${ }^{238} \mathrm{U} /{ }^{206} \mathrm{~Pb}$ age of the oldest three concordant ages from the gabbro was $493 \pm 2$ Ma (MSWD=0.36), interpreted as the magmatic age of the gabbro (Figs. 8a, 9). The $2 \sigma$ analytical uncertainty is low because only three analyses with high precision were used to calculate the mean. Three younger zircons with ages around $470 \mathrm{Ma}$ are possibly attributable to veins of granitic material of that age (from the adjacent intrusion, as mentioned above) having been accidentally included in the whole-rock sample from which these zircons were separated. The two youngest ages are interpreted as having experienced $\mathrm{Pb}$ loss.

The tonalite intrusion sampled near Leaghan, in the Tyrone Volcanic Group (sample TY07050204), yielded 10 Palaeozoic zircon grains (Fig. 10) with U concentrations 93-368 ppm. The ages are all concordant but vary in age from 499 to 454 Ma. It is possible that the zircons of approximately 490 Ma were inherited from earlier arc magmatism (such as that of the Tyrone Plutonic Group, as in our gabbro sample discussed above), but the distinctive high-U composition of the zircons in the gabbro (sample TY07043003) was not observed in the tonalite zircon sample. It is also possible that the two younger zircons experienced $\mathrm{Pb}$ loss, but the low $\mathrm{U}$ concentrations in the tonalite zircons makes this less likely. A weighted mean of all of the Palaeozoic ${ }^{206} \mathrm{~Pb} /{ }^{238} \mathrm{U}$ ages is $475 \pm 10 \mathrm{Ma}$, with a high MSWD (Fig. 8b). We also dated Archaean cores in three zircon grains from the Leaghan tonalite sample using SHRIMP and LAMC-ICPMS (laser ablation multi-collector inductively coupled plasma mass spectrometry); two of those dates are concordant and have ${ }^{207} \mathrm{~Pb} /{ }^{206} \mathrm{~Pb}$ ages of $2.25 \mathrm{Ga}$ and $2.32 \mathrm{Ga}$. The other was discordant and has a ${ }^{207} \mathrm{~Pb} /{ }^{206} \mathrm{~Pb}$ age of $2.58 \mathrm{Ga}$.

\section{Discussion}

\section{Tectonic Affinity of the Tyrone Igneous Complex}

The pervasive supra-subduction-zone and island-arc-tholeiite geochemical signatures in rocks of the TIC, together with their Early Ordovician age, confirm that these units formed within an intra-oceanic subudction-zone setting in the Iapetus Ocean and thus are part of the accreted island-arc terrane complex within the Grampian suture. 
We interpret the Tyrone Plutonic Group and Tyrone Volcanic Group to represent, respectively, the primitive intra-oceanic phase of the Lough Nafooey Arc and the synand post-collisional upper crust of the accreted arc. Although consistent with the oceaniccrust interpretation of Hutton et al. (1985), the geochemical characteristics of the Tyrone Plutonic Group indicate it is not an ophiolite formed at a mid-ocean ridge, but one that formed by magmatism at a subduction zone, as have most large ophiolites (Bloomer et al. 1995).

Having correlated the TIC with other accreted-arc units in the Grampian suture zone, we can use geochemistry and $\mathrm{Nd}$ isotopic composition to compare Grampian tectonics recorded by rocks in the TIC with those in South Mayo and Connemara, situated $170 \mathrm{~km}$ to the southwest (Fig. 11). As the most primitive portions of the TIC, mafic assemblages of the Tyrone Plutonic Group have trace-element signatures and Nd isotope ratios similar to, or more primitive than, those of modern western Pacific intraoceanic arcs (Fig. 6; e.g., Ewart \& Hawkesworth 1987; Pearce et al. 2005). Disregarding gabbro samples from Craigballyharky that were likely contaminated by granitic intrusion around $471 \mathrm{Ma}$ (the gabbro being LREE-enriched and with $\varepsilon_{\mathrm{Nd}(\mathrm{t})}$ of -5.9), mafic units of the Tyrone Plutonic Group apparently formed in a purely intra-oceanic subduction setting in Tremadoc time (са. $493 \mathrm{Ma}$ ) with no continent-derived material involved in petrogenesis. As such, these mafic units are inferred to correlate with primitive basalts of the Bohaun Group and the lower Lough Nafooey Group of South Mayo (Fig. 11; Clift \& Ryan 1994; Draut \& Clift 2001).

Through late Tremadoc time (as early as $490 \mathrm{Ma}$; Chew et al. 2007), the Lough Nafooey arc neared the continental margin of Laurentia, and, along at least part of the subduction zone, amalgamated with a microcontinental terrane outboard of Laurentia before full arc-continent collision began (Waldron \& van Staal 2001; Flowerdew et al. 2005; Chew et al. 2008). Given the proximity of the TIC to the Slishwood Division (Fig. 1) and the fault-bounded Tyrone Central Inlier, early Arenig magmatism recorded in the TIC probably reflects amalgamation of the oceanic arc with a continental fragment, most likely the Tyrone Central Inlier as proposed by Chew et al. (2008). Such an event could explain the lowering of $\varepsilon_{\mathrm{Nd}(\mathrm{t})}$ values, but not as low as to normal continental values; $\boldsymbol{\varepsilon}_{\mathrm{Nd}(\mathrm{t})}$ 
of +2.4 observed in mafic volcanism at Lougham Crory is still substantially more primitive than Laurentian (Dalradian) crust (Draut et al. 2004). Similar lowering of Nd isotopic ratios to weakly oceanic values occurs in the upper Lough Nafooey Group of South Mayo, a stage referred to as “soft collision” (involving continental sediment and outermost continental crust) by Draut et al. (2002).

By early to middle Arenig time (ca. 478-475 Ma), "hard” collision (orogeny and regional deformation) is inferred to be the reason for strongly LREE-enriched volcanism at Lougham Crory, southeast of Greencastle, and elsewhere in the Tyrone Volcanic Group. This tectonic stage would have involved collision of an amalgamated arcmicrocontinent with the Laurentian margin, which was under way at least by ca. $474 \mathrm{Ma}$, based on the ages of the oldest syn-collisional intrusions in Connemara (Friedrich et al. 1999; Fig. 11), and which are consistent with our $475 \pm 10 \mathrm{Ma}$ U-Pb zircon age obtained for the Leaghan tonalite (Fig. 8b). Our new data are consistent, therefore, with the tectonic model illustrated by Chew et al. (2008). Subduction-related trace-element signals persisted in the Tyrone Volcanic Group (e.g., relative Nb depletion; Fig. 6), possibly reflecting development of a continental arc as subduction polarity reversed (Dewey \& Ryan 1990). Tonalitic-granitic intrusion accompanied this stage of orogeny and subduction polarity flip, affecting rocks of both the Tyrone Plutonic Group and the Tyrone Volcanic Group. Intrusion and eruption of silicic melts concentrated around 475$471 \mathrm{Ma}$ in the TIC (our tonalite date and those of Hutton et al. 1985 and Cooper et al. 2008), but continued until $462 \mathrm{Ma}$ in Connemara as the orogen collapsed and was exhumed (Friedrich et al. 1999; Clift et al. 2004). As in volcanic rocks of the Tourmakeady Group in South Mayo, TIC petrogenesis accompanying hard collision involved recycling of continental material. Continental wallrock incorporated by intruding melt explains the strongly continental $\boldsymbol{\varepsilon}_{\mathrm{Nd}(\mathrm{t})}$ values in Tyrone Volcanic Group samples and the presence of Archaean zircons in the Leaghan tonalite; the most evolved TIC samples show that intrusion occurred in a syn- or post-collisional setting (Fig. 7). Similar to the $2.58 \mathrm{Ga}$ zircon core found in our Leaghan tonalite sample, detrital zircons from metasedimentary rocks in the Tyrone Central Inlier (Chew et al. 2008) and in the Argyll and Southern Highland Groups of the Dalradian metasedimentary rocks in Scotland (Cawood et al. 2003, 2007) contain populations dated to 2.5-2.7 Ga. 
The tectonic affinity of rocks sampled in three quarries near Mountfield (Tyrone Volcanic Group) remains unclear. Sampled rock types included fresh pyroxene-phyric basalt and tectonized basalt with minor quartz veins. At one quarry, metasedimentary rocks (not sampled) appeared to be tectonically interleaved with basalt, although the basalt composition sampled there (sample TY07050201) did not differ substantially from samples at other Mountfield quarries where metasedimentary rocks are absent. The lack of a strong relative $\mathrm{Nb}$ depletion demonstrates that the Mountfield volcanic rocks were not generated above a rapidly subducting oceanic slab. Mountfield basalts are also more evolved than other mafic rocks of the TIC (Fig. 3), and show within-plate magmatic affinity according to the scheme of Pearce \& Cann (1973; Figs. 4, 7), though they display

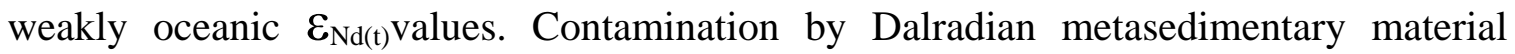
during shearing along the Omagh Thrust is considered unlikely because addition of any fluid derived from Dalradian rocks would be expected to cause further relative depletion of fluid-immobile Nb. Based on their stratigraphic position near the top of the TIC volcanic exposures (Cooper et al. 2008), we infer that the Mountfield basalts most likely formed late in the Grampian Orogeny when no strong plate underthrusting occurred, perhaps contemporaneously with subduction polarity reversal and/or gravitationally induced loss of the lower crust. The lower degree of LREE enrichment in Mountfield samples compared to others from the Tyrone Volcanic Group is consistent with high heat flow having increased the melting percentage late in the orogeny, as would occur after lower crustal loss (Kay \& Kay 1993).

\section{The Grampian-Taconic Orogen and Formation of Continental Crust}

Silicic lavas of the Tyrone Volcanic Group, as well as the tonalite and granite that intrude the TIC, show pronounced relative enrichment of LREEs, as reflected by the $\mathrm{La} / \mathrm{Sm}$ ratios (Fig. 11). Some of these rocks are more LREE-enriched than bulk continental crust (which has chondrite-normalized La/Sm of 3.0; Taylor \& McLennan 1981; Rudnick \& Fountain 1995), and some are more LREE-enriched than typical Irish Dalradian composition, from which material was incorporated in syn-collisional melts (average chondrite-normalized La/Sm ranges from 0.5 to 3.5 for various Irish Dalradian units, based on calculations using data of Senior \& Leake 1978). Pronounced LREE 
enrichment in syn- and post-collisional volcanic units of the TIC, South Mayo, and some Connemara plutons indicates that crystal fractionation played an important role during and after Grampian collision, enriching magmatism more than could occur simply from mixing of continental and primitive-arc melts (cf. Draut et al. 2002). Using the standard equation for fractional crystallization, assuming a typical basaltic parent melt of $20 \%$ olivine, 30\% clinopyroxene, and 50\% plagioclase, and using bulk partition coefficients of La and Sm in the parent melt of 0.1131 and 0.1709, respectively (Rollinson 1993), a chondrite-normalized La/Sm ratio of 4 is reached when fractional crystallization has progressed far enough that the melt fraction is reduced to $\sim 40 \%$. Chondrite-normalized $\mathrm{La} / \mathrm{Sm}$ ratios above 5 , seen in one TIC sample (a dacite collected southeast of Greencastle), require melt fractions $<2 \%$. Derivation of all the TIC magmatic products by crystal fractionation in only one parent magma is neither required nor likely; such calculations simply demonstrate that this degree of LREE enrichment can be readily attained by crystal fractionation but cannot be explained only by mixing bulk continental melt with mafic arc melt (because the degree of LREE enrichment in some TIC samples is substantially higher than that of continental crust). Because new, mantle-derived magmatism constituted at least $20 \%$ of the crustal material accreted in the Grampian collision, rather than merely re-melting of pre-existing crust (calculations of Draut et al. 2004), the highly enriched character of that much new crust could effectively drive the bulk composition of the accreted arc terrane toward the composition of average (andesitic, LREE-enriched) continental crust, especially if accompanied by loss of corresponding dense lower-crustal residues (discussed below).

Having demonstrated the highly LREE-enriched composition of volcanic and plutonic units emplaced during the Grampian Orogeny into the TIC (this study) as well as in South Mayo and Connemara (Draut et al. 2002), it is worthwhile to assess whether such trends represent isolated occurrences of super-enriched magmatism in Ireland or are also present elsewhere along the Caledonide suture. Calculations using ICP-MS traceelement data of Steinhoefel et al. (2008) from the Grampian Highlands in Scotland, associated with the same arc-continent collision, show only one granitic syn-collisional intrusion more LREE-enriched than both average continental crust and typical Dalradian compositions (sample M-4 of Steinhoefel et al. 2008, with a chondrite-normalized La/Sm 
ratio of 4.92). However, LREE enrichment was consistently greater than that of Dalradian and bulk continental crust in Grampian Highland intrusions that represent later continental arc activity and the docking of the Avalonian continental block against Laurentia (several intrusions with $\mathrm{La} / \mathrm{Sm}>5$; Steinhoefel et al. 2008; Oliver et al. 2008).

Farther along the strike of the Grampian-Taconic Orogen, super-enriched syncollisional magmatism is also apparent in the 50-km-wide Notre Dame subzone, Newfoundland, identified as containing Ordovician accreted arc units approximately equivalent to those studied in Ireland and Scotland (e.g., Whalen et al. 1997; van Staal et al. 1998, 2007). Within the Notre Dame subzone, 35 of 172 samples that span the age range of the Grampian-Taconic Orogeny show chondrite-normalized La/Sm ratios $>4$, ranging to >10 (our calculations using data from Whalen et al. 1997 and Rogers 2004). These highly enriched compositions occur in the Cape Ray granodiorite complex (488 Ma) and the Cormacks Lake tonalitic orthogneiss (483 Ma), both identified by van Staal et al. (2007) as associated with the first phase of Notre Dame arc activity (i.e., amalgamation of the Notre Dame arc and Dashwoods microcontinent; 490-480 Ma). Strong LREE enrichment continued during the second phase of Notre Dame arc activity, as the Dashwoods terrane collided with Laurentia, reflected in igneous complexes dated to 480-459 Ma (Southwest Brook and Hungry Mountain Complexes; van Staal et al. 2007). We infer, therefore, that the eruption and intrusion of super-enriched magmatism associated with this Ordovician arc-continent collision was not a rare phenomenon restricted to one part of the Irish Caledonides, but was spatially and temporally pervasive during the Grampian-Taconic Orogeny. As such, the generation of melts more enriched than the local continental crust during an arc accretion event is likely a common process widespread enough to drive the bulk composition of accreted crust toward typical continental values on a regional scale.

In addition to the formation of highly enriched melts, loss of corresponding dense, depleted residues (cumulates) in the lower crust is also required for accreted arc crust to attain a composition close to that of continental material. Removal of the lower crust by delamination (Bird 1978) or convective instability (Jull \& Kelemen 2001) is believed to have occurred in other arc settings (e.g., Kay et al. 1994; Ducea \& Saleeby 1998), and may have contributed to rapid orogenic exhumation and collapse after the Grampian 
Orogeny in western Ireland (Flowerdew et al. 2000; Draut et al. 2002). Seismic profiles across the Caledonide suture zone show that no Ordovician lower crust is present today beneath Connemara (Klemperer et al. 1991), although the timing of its loss cannot be known with certainty. We speculate that the anomalous geochemistry of the Mountfield samples relative to other Tyrone Volcanic Group units (within-plate affinity, less LREE enrichment, and weak or absent subduction-zone signature) may have been related to magmatism following loss of the lower crust in the late stages of the Grampian Orogeny. In terms of their mafic composition and trace-element characteristics (e.g., La/Yb ratios and lack of relative HFSE depletion) our Mountfield samples resemble lavas from the Puna Plateau of the Andes, which are associated with melting above a zone of lowercrustal loss (Kay \& Kay 1993).

\section{Conclusions}

Primitive mafic intrusions of the Tyrone Igneous Complex, Ireland, indicate intraoceanic arc activity no later than ca. 493 Ma (Tremadoc), followed by a transition to more enriched magmatism as arc-continent collision began. LREE-enriched sialic magmatism linked to mixing of mantle melts with Laurentian continental material had begun by early Arenig time, as is evident from incorporation of Archaean zircon grains into a tonalite intrusion ca. $475 \mathrm{Ma}$. The degree of LREE enrichment in Arenig volcanism and silicic intrusions of the TIC exceeds that of the Dalradian continental material which would have been thrust under the colliding forearc and potentially recycled into arc magmatism. Magmatic compositions therefore cannot be explained simply by mixing primitive melts with assimilated continental material. Rather, substantial crystal fractionation (melt fractions 2-40\%) must have accompanied the formation of new crust in the Grampian-Taconic Orogeny. As the super-enrichment of orogenic melts is observed elsewhere in the Caledonide suture in both the British Isles and in Newfoundland, the addition of new, highly enriched melt to this accreted arc terrane was apparently widespread, and, particularly if accompanied by loss of the dense lower crust, could drive the bulk composition of accreted crust toward that of enriched continental crust. This, therefore, supports the theory that arc-continent collision has played an important role in forming extant continental crust. 


\section{Acknowledgements}

This work was supported by the University of Aberdeen. LA-MC-ICPMS dating was conducted at the Arizona LaserChron Center with the assistance of George Gehrels and Victor Valencia and was supported by NSF-EAR 0443387. Joseph Wooden helped acquire the U-Pb data at the USGS/Stanford University SHRIMP facility. We thank Joseph Whalen and Alexandre Zagorevski (Geological Survey of Canada) for providing geochemical data from the Notre Dame subzone, Padraig Leonard (Carrickmore Quarry) and the staff of the Mountfield Quarry for field support, Robyn Hannigan (Arkansas State University) for supplemental laboratory analyses, and David Chew (Trinity College, Dublin) for stimulating discussions. Comments by Patrick Barnard and James Hein (USGS) substantially improved earlier versions of the manuscript. We thank Michael Flowerdew, one anonymous reviewer, and editor Alan Collins for their constructive reviews.

\section{Figure Captions}

Table 1. Sample numbers, localities (in Irish grid coordinates), and rock types; (A) majorelement percentages, and loss-on-ignition; (B) Trace- and rare-earth-element concentrations (ppm) and $\mathrm{Nd}$ isotopic ratios of TIC whole-rock samples. Nd isotopic

results are reported as measured ${ }^{143} \mathrm{Nd} /{ }^{144} \mathrm{Nd}$ ratios and as $\varepsilon_{\mathrm{Nd}(\mathrm{t})}$, age-corrected for decay of ${ }^{147} \mathrm{Sm}$ to ${ }^{143} \mathrm{Nd}$ (using Sm and Nd concentrations obtained by ICP-MS analyses and assuming an age of $470 \mathrm{Ma})$.

Table 2. U-Pb zircon data collected by SHRIMP and LA-ICP-MS.

Figure 1. Geologic map of the Tyrone Igneous Complex (TIC), based on published maps (Institute of Geological Sciences 1978a, $b$; Geological Survey of Northern Ireland 1995). Sampled localities are indicated in the TIC, with the final five digits of sample numbers 
(see Table 1 for full sample names and descriptions). The intrusion dated by Hutton et al. (1985) was sampled in the Craigballyharky area near our samples TY07043001-3. The region shown as "other volcanic rocks" contains poorly exposed rocks mapped by the Geological Survey of Northern Ireland as basalts and basaltic andesites. Inset map shows the TIC in the context of the Caledonide suture zone in the British Isles: major faults (GGF, Great Glen Fault; HBF, Highland Boundary Fault; FCBL, Fairhead-Clew Bay Line; SUP, Southern Uplands Fault) and the Midland Valley Terrane (MVT) of Scotland, as well as Grampian exposures in Ireland (Connemara, South Mayo, Slishwood Division, and TIC). Line A-A' shows the orientation of the schematic cross-section in Figure 2.

Figure 2. Schematic cross-section across the Tyrone Igneous Complex from northwest to southeast, oriented along the line $\mathrm{A}-\mathrm{A}^{\prime}$ on Figure 1 (after Chew et al. 2008 and Geological Survey of Northern Ireland maps).

Figure 3. Plot of silica vs. alkali components in all TIC samples, with the division between tholeiitic and alkaline compositions indicated for the mafic end of the spectrum (after Rollinson 1993).

Figure 4. Ternary Ti/100-Zr-Yx3 discrimination diagram for TIC (mafic samples only), after Pearce \& Cann (1973). Polygonal fields represent (A) island-arc tholeiites; (B) midocean-ridge basalt (MORB); (C) calc-alkali basalts; (D) within-plate basalts.

Figure 5. Chondrite-normalized rare-earth-element (REE) plots for all TIC samples; C1 chondrite values from Anders \& Grevesse (1989). For comparison, the shaded regions show the range of average REE compositions of lavas from various parts of the intraoceanic Mariana Arc (from Pearce et al. 2005).

Figure 6. Multi-element discrimination diagrams (after Pearce 1982) for all TIC samples, with element concentrations normalized against normal mid-ocean-ridge basalt $(\mathrm{N}$ MORB) values of Sun \& McDonough (1989). For comparison, the shaded regions show 
the range of average compositions of lavas from various parts of the intra-oceanic Mariana Arc (from Pearce et al. 2005).

Figure 7. All TIC samples plotted on a Rb-(Nb $+\mathrm{Y})$ discrimination diagram (after Pearce et al. 1984). Fields indicate syn-collisional granites (syn-COLG), within-plate granites (WPG), volcanic-arc granites (VAG), and ocean-ridge granites (ORG). The field for postcollisional granites (post-COLG) overlaps those of syn-COLG, VAG, and WPG.

Figure 8. U-Pb concordia diagrams for (A) zircon grains from a gabbro sampled at Craigballyharky (Tyrone Plutonic Group, sample TY07043003), and (B) zircon grains in a tonalite sampled near Leaghan (Tyrone Volcanic Group, sample TY07050204). In (A), the weighted mean of three concordant ages from the gabbro was $493 \pm 2$ Ma. Younger ages are likely attributable to the presence of younger, intruded granitic material in the sample, or to $\mathrm{Pb}$ loss in high-U grains (see text). In (B), the Paleozoic-aged zircon grains gave concordant ages with a weighted mean of $475 \pm 10$ Ma. Cores in three other zircons from the Leaghan tonalite yielded Archaean ages (2.25, 2.32, and $2.58 \mathrm{Ga}$ ).

Figure 9. Cathodoluminescence (CL) images of zircon grains analysed from sample TY07043003, a gabbro within the Tyrone Plutonic Group near Craigballyharky. Scale bar is $100 \mu \mathrm{m}$. Point numbers refer to analyses shown in Table 2. White spots indicate analysis location. The dark CL images for this sample resulted from extremely high (>2000 ppm) U concentrations.

Figure 10. Cathodoluminescence (CL) images of zircon grains analysed from sample TY07050204, a tonalite within the Tyrone Volcanic Group near Leaghan. Scale bar is $100 \mu \mathrm{m}$. Point numbers refer to analyses shown in Table 2 . White spots indicate analysis location.

Figure 11. Proposed correlation of Grampian rock units and tectonic history across three areas of the Irish Caledonides: South Mayo, Connemara, and the Tyrone Igneous Complex (TIC). Stratigraphy of volcanic and volcaniclastic sedimentary formations in 
South Mayo was defined by Graham et al. (1989). Ages of igneous intrusions in Connemara are taken from Friedrich et al. (1999); DCD is the Dawros-CurrywongaunDoughruagh intrusion, CLW is the Cashel-Lough Wheelaun gabbro. Tectonic affinity of South Mayo and Connemara units was interpreted by Dewey \& Ryan (1990), Clift \& Ryan (1994), Dewey \& Mange (1999), Friedrich et al. (1999), Clift et al. 2004, Draut et al. (2004), and others. $\varepsilon_{\mathrm{Nd}(t)}, \mathrm{SiO}_{2}$, and $\mathrm{La} / \mathrm{Sm}$ ratios (a measure of LREE enrichment, here normalized against chondrite values of Anders \& Grevesse 1989) are plotted for TIC samples using U-Pb ages from this study, Hutton et al. (1985), and Cooper et al. (2008) to constrain intrusion and volcanism where possible, and estimating likely ages of other samples based on geochemical characteristics. $\mathcal{E}_{\mathrm{Nd}(\mathrm{t})}$ is age-corrected to $470 \mathrm{Ma}$. On the $\mathrm{La} / \mathrm{Sm}$ plot, the shaded area represents chondrite-normalized $\mathrm{La} / \mathrm{Sm}$ ratio for Irish Dalradian rocks (hundreds of samples analyzed by Senior \& Leake 1978) and the dashed line shows the chondrite-normalized $\mathrm{La} / \mathrm{Sm}$ ratio of average continental crust (Taylor \& McLennan 1981; Rudnick \& Fountain 1995). Notably, LREE enrichment (La/Sm) is greater in some TIC samples than in the Dalradian units with which primitive Ordovician arc magma would have mixed. This implies that crystal fractionation, not mixing alone, is important in generating magmatism associated with the arc-continent collision.

\section{References}

Alsop, G.I. \& HutTon, D.H.W. 1993. Major southeast-directed Caledonian thrusting and folding in the Dalradian rocks of mid-Ulster; implications for Caledonian tectonics and mid-crustal shear zones. Geological Magazine, 130, 233-244.

Anders, E. \& Grevesse, N. 1989. Abundances of the elements: Meteoritic and solar. Geochimica et Cosmochimica Acta, 53, 197-214.

Armstrong, H.A. \& Owen, A.W. 2001. Terrane evolution of the paratectonic Caledonides of northern Britain. Journal of the Geological Society, London, 158, 475-486.

BIRD, P. 1978. Initiation of intracontinental subduction in the Himalaya. Journal of Geophysical Research, 83, 4975-4987. 
Bloomer, S.H., Taylor, B., Macleod, C.J., Stern, R.J., Fryer, P. \& Johnson, L. 1995. Early arc volcanism and the ophiolite problem: a perspective from drilling in the Western Pacific. In Active Margins and Marginal Basins of the Western Pacific. (Eds, B. TAYlOR AND J. NATland), Washington D.C.: American Geophysical Union, Geophysical Monograph Series, 88, 67-96.

BLucK, B.J. 1985. The Scottish paratectonic Caledonides. Scottish Journal of Geology 21, 437-464.

Bryan, W.B., StiCE, G.D. \& EwART, A. 1972. Geology, petrography, and geochemistry of the Volcanic Islands of Tonga. Journal of Geophysical Research, 77, 1566-1585.

Cawood, P.A., Nemchin, A.A., Smith, M. \& Loewy, S. 2003. Source of the Dalradian Supergroup constrained by $\mathrm{U}-\mathrm{Pb}$ dating of detrital zircon and implications for the East Laurentian margin. Journal of the Geological Society, London, 160, 231-246.

Cawood, P.A., Nemchin, A.A., Strachan, R.A., Prave, T. \& Krabbendam, M. 2007. Sedimentary basin and detrital zircon record along East Laurentia and Baltica during assembly and breakup of Rodinia. Journal of the Geological Society, London, 164, 257-275.

Chew, D.M., Graham, J.R. \& Whitehouse, M.J. 2007. U-Pb zircon geochronology of plagiogranites from the Lough Nafooey (= Midland Valley) arc in western Ireland: constraints on the onset of the Grampian orogeny. Journal of the Geological Society, London, 164, 747-750.

Chew, D.M., Flowerdew, M.J., Page, L.M., Crowley, Q.G., Daly, J.S., Cooper, M. \& Whitehouse, M.J. 2008. The tectonothermal evolution and provenance of the Tyrone Central Inlier, Ireland: Grampian imbrication of an outboard Laurentian microcontinent? Journal of the Geological Society, London, 165, 675-685.

Cliff, R.A., YARDley, B.W.D. \& Bussy, F. 1996. U-Pb and Rb-Sr geochronology of magmatism and metamorphism in the Dalradian of Connemara, W. Ireland. Journal of the Geological Society, London 153, 109-120.

CLIFT, P.D. \& RYAN, P.D. 1994. Geochemical evolution of an Ordovician island arc, South Mayo, Ireland. Journal of the Geological Society, London, 151, 329-342.

CLIFT, P.D. \& VAnNuCCHI, P. 2004. Controls on tectonic accretion versus erosion in subduction zones: Implications for the origin and recycling of the continental crust, 
Reviews of Geophysics, 42, RG2001, doi:10.1029/2003RG000127.

Clift, P.D., Dewey, J.F., Draut, A.E., Chew, D.M., Mange, M. \& Ryan, P.D. 2004. Rapid tectonic exhumation, detachment faulting and orogenic collapse in the Caledonides of western Ireland. Tectonophysics, 384, 91-113.

Cooper, M.R., Crowley, Q.G. \& Rushton, A.W.A. 2008. New age constraints for the Ordovician Tyrone Volcanic Group, Northern Ireland. Journal of the Geological Society, London, 165, 333-339.

DAVIDSON, J.P. 1996. Deciphering Mantle and Crustal Signatures in Subduction Zone Magmatism. Geophysical Monograph 96, American Geophysical Union, 251-262.

DeBari, S.M. \& Coleman, R.G. 1989. Examination of the deep levels of an island arc: evidence from the Tonsina ultramafic-mafic assemblage, Tonsina, Alaska. Journal of Geophysical Research, 94, 4373-4391.

DePaolo, D.J. \& Wasserburg, G.J. 1976. Nd isotopic variations and petrogenetic models. Geophysical Research Letters 3, 249-252.

Dewey, J.F. \& Shackleton, R.M. 1984. A model for the evolution of the Grampian tract in the early Caledonides and Appalachians. Nature, 312, 115-121.

Dewey, J.F. \& Ryan, P.D. 1990. The Ordovician Evolution of the South Mayo Trough, western Ireland. Tectonics, 9, 887-901.

Dewey, J.F. \& Mange, M. 1999. Petrology of Ordovician and Silurian sediments in the Western Irish Caledonides: Tracers of short-lived Ordovician continent-arc collision orogeny and the evolution of the Laurentian Appalachian-Caledonian margin. In: MacNiocaill, C., and Ryan, P. D. (eds), Continental tectonics. Geological Society of London, Special Publication 164, 55-108.

DrAut, A.E. \& ClifT, P.D. 2001. Geochemical evolution of arc magmatism during arccontinent collision, South Mayo, Ireland. Geology, 29, 543-546.

Draut, A.E., Clift, P.D., Hannigan, R.E., Layne, G. \& Shimizu, N. 2002. A model for continental crust genesis by arc accretion: rare earth element evidence from the Irish Caledonides. Earth and Planetary Science Letters 203, 861-877.

Draut, A.E., Clift, P.D., Chew, D.M., CoOper, M.J., TaYlor, R.N., and Hannigan, R.E. 2004. Laurentian crustal recycling in the Ordovician Grampian Orogeny: Nd isotopic evidence from western Ireland. Geological Magazine, 141, 195-207.

Draut et al. page 22 of 27 
Ducea, M. \& Saleeby, J. 1998. A case for delamination of the deep batholithic crust beneath the Sierra Nevada, California. International Geology Review, 40, 78-93.

ElLAM, R.M. \& HAWKESWORTH, C.J. 1988. Elemental and isotopic variations in subduction related basalts: evidence for a three component model. Contributions to Mineralogy and Petrology, 98, 72-80.

Ewart, A. \& Hawkesworth, C.J. 1987. The Pleistocene-recent Tonga-Kermadec Arc lavas; interpretation of new isotopic and rare earth data in terms of a depleted mantle source model. Journal of Petrology 28, 495-530.

Fitton, J.G., Saunders, A.D., Larsen, L.M., Hardarson, B.S. \& Norry, M.J. 1998. Volcanic rocks from the southeast Greenland margin at $63 \mathrm{~N}$ : composition, petrogenesis and mantle sources. Proceedings of the Ocean Drilling Program, Scientific Results, 152, 331-350.

FitTon, J.G. \& GodARD, M. 2004. Origin and evolution of magmas on the Ontong Java Plateau. In: J.G. Fitton, J.J. Mahoney, P.J. Wallace \& A.D. Saunders (eds.) Origin and evolution of the Ontong Java Plateau, Geological Society Special Publication 229, 151-178,

Flowerdew, M.J., Daly, J.S., Guise, P.G. \& ReX, D.C. 2000. Isotopic dating of overthrusting, collapse and related granitoid intrusion in the Grampian orogenic belt, northwestern Ireland. Geological Magazine, 137, 419-435.

FlowerdeW, M.J., DALY, J.S. \& Whitehouse, M.J. 2005. 470 Ma granitoid magmatism associated with the Grampian Orogeny in the Slishwood Division, NW Ireland. Journal of the Geological Society, London, 162, 563-575.

Friedrich, A.M., Hodges, K.V., Bowring, S.A. \& MARTin, M.W. 1999. Geochronological constraints on the magmatic, metamorphic, and thermal evolution of the Connemara Caledonides, western Ireland. Journal of the Geological Society, London, 156, 1217-1230.

Gehrels, G.E., Valencia, V.A. \& Ruiz, J. 2008. Enhanced precision, accuracy, efficiency, and spatial resolution of U-Pb ages by laser ablation multicollector inductively coupled plasma mass spectrometry. Geochemistry, Geophysics, Geosystems, 9, Q03017, doi:10.1029/2007GC001805. 
GeOlogical Survey of Northern Ireland. 1995. Draperstown, Northern Ireland

Sheet 26. Solid and drift geology, 1:50,000, British Geological Survey, Keyworth, Nottingham.

Gradstein, F.M., OgG, J.G. \& SMith, A.G. 2004. A geologic time scale 2004. Cambridge University Press, 610 p.

Graham, J.R., LEAKE, B.E. \& RYAN, P.D. 1989. The Geology of South Mayo, western Ireland. Publication of the Department of Geology and Applied Geology, University of Glasgow, 75 p.

Hartley, J.J. 1933. The geology of North-Eastern Tyrone and adjacent portions of Co. Londonderry. Proceedings of the Royal Irish Academy B41, 218-285.

HARTLEY, J.J. 1936. The age of the igneous series of Slieve Gallion, Northern Ireland. Geological Magazine 73, 226-228.

Hawkesworth, C.J. \& Kemp, A.I.S. 2006. Evolution of the continental crust. Nature, 443, 811-817.

Holbrook, W.S., Lizarralde, D., McGeary, S., Bangs, N. \& Diebold, J. 1999. Structure and composition of the Aleutian island arc and implications for continental crust growth. Geology, 27, 31-34.

HutTon, D.H.W. \& Holland, C.H. 1992. An Arenig-Llanvirn age for the black shales of Slieve Gallion, County Tyrone. Irish Journal of Earth Sciences 11, 187-189.

Hutton, D.H.W., Aftalion, M. \& Halliday, A.N. 1985. An Ordovician ophiolite in County Tyrone, Ireland. Nature, 315, 210-212.

Institute of GeOlogical Sciences. 1987a. Cookstown, Northern Ireland Sheet 27. Solid edition, 1:50,000, Ordnance Survey, Southampton.

Institute of Geological ScienCes. 1978b. Pomeroy, Northern Ireland Sheet 34. Solid edition, 1:50,000, Ordnance Survey, Southampton.

Karabinos, P., Samson, S.D., Hepburn, J.C. \& Stoll, H.M. 1998. Taconian Orogeny in the New England Appalachians; collision between Laurentia and the Shelburne Falls Arc. Geology, 26, 215-218.

KAY, R.W. \& KAY, S.M. 1993. Delamination and delamination magmatism. Tectonophysics, 219, 177-189. 
Kay, S., CoirA, B. \& Viramonte, J. 1994. Young mafic back arc volcanic rocks as indicators of continental lithospheric delamination beneath the Argentine Puna plateau, central Andes. Journal of Geophysical Research, 99, 24,323-24,339.

Kelemen, P.B., HanghøJ, K. \& Greene, A.R. 2003. One view of the geochemistry of subduction-related magmatic arcs with an emphasis on primitive andesite and lower crust, in Rudnick, R.L., ed., The Crust, Treatise on Geochemistry, v. 3 (Holland, H.D. and Turekian, K.K., eds.), Elsevier-Pergamon, Oxford, p. 593-659.

KLEMPERER, S.L., RyAN, P.D. \& SNyDER, D.B. 1991. A deep seismic reflection transect across the Irish Caledonides. Journal of the Geological Society, London, 148, 149164.

LudwiG, K.R. 2001. Squid 1.02: Berkeley Geochronology Center Special Publication 2.

LUDWIG, K.R. 2003. Isoplot/Ex 3.00: A geochronological toolkit for Microsoft Excel: Berkeley Geochronology Center Special Publication 4.

McKerrow, W.S., Dewey, J.F. \& Scotese, C.R. 1991. The Ordovician and Silurian development of the Iapetus Ocean. Special Papers in Palaeontology, 44, 165-178.

Miller, D.J. \& Christensen, N.I. 1994. Seismic signature and geochemistry of an island arc: a multidisciplinary study of the Kohistan accreted terrane, northern Pakistan. Journal of Geophysical Research, 99, 11,623-11,642.

Oliver, G.J.H., WiLDE, S.A. \& WAN, Y. 2008. Geochronology and geodynamics of Scottish granitoids from the late Neoproterozoic break-up of Rodinia to Palaeozoic collision. Journal of the Geological Society, London, 165, 661-674.

PearCe, J.A. \& CANN, J.R. 1973. Tectonic setting of basic volcanic rocks determined using trace element analyses. Earth and Planetary Science Letters, 19, 290-300.

Pearce, J.A. 1982. Trace element characteristics of lavas from destructive plate boundaries. In: Thorpe, R.S. (ed.) Andesites. John Wiley, Chichester, 525-548.

Pearce, J.A., Harris, N.B.W. \& Tindle, A.G. 1984. Trace element discrimination diagrams for the tectonic interpretation of granitic rocks. Journal of Petrology, 25, 956-983.

Pearce, J.A., Stern, R.J., Bloomer, S.H. \& Fryer, P. 2005. Geochemical mapping of the Mariana arc-basin system: Implications for the nature and distribution of 
subduction components. Geochemistry Geophysics Geosystems, 6, doi: 10.1029/2004GC000895

Pearcy, L.G., Debari, S.M. \& SleEP, N.H. 1990. Mass balance calculations for two sections of island arc and implications for the formation of continents. Earth and Planetary Science Letters, 96, 427-442.

Rogers, N. 2004. Red Indian Line geochemical database. Geological Survey of Canada Open File 4605.

RolLiNSON, H. 1993. Using geochemical data: evaluation, presentation, interpretation. Harlow, Pearson, Prentice Hall, 352 p.

RUDNICK, R.L. \& FounTAIN, D.M. 1995. Nature and composition of the continental crust; a lower crustal perspective. Reviews of Geophysics, 33, 267-309.

SenioR, A. \& LeaKe, B.E. 1978. Regional metamorphism and the geochemistry of the Dalradian metasediments of Connemara, western Ireland. Journal of Petrology, 19, 585-625.

StACEY, J.S. \& KRAMERS, J.D. 1975. Approximation of terrestrial lead isotope evolution by a two-stage model. Earth and Planetary Science Letters, 26, 207-221.

StEIGER, R.H. \& JÄGER, E. 1977. Subcommission on Geochronology: Convention on the use of decay constants in geo- and cosmochronology. Earth and Planetary Science Letters, 36, 359-362.

Steinhoefel, G., Hegner, E. \& Oliver, G.J.H. 2008. Chemical and $\mathrm{Nd}$ isotope constraints on granitoid sources involved in the Caledonian Orogeny in Scotland. Journal of the Geological Society, London, 165, 817-827.

StILLMAN, C.J. 1981. Caledonian igneous activity, in Holland, C.H., ed., A geology of Ireland: New York, John Wiley \& Sons, 83-106.

Sun, S.-S. \& McDonough, W.F. 1989. Chemical and isotopic systematics of oceanic basalts: implications for mantle compostion and processes. In: Saunders, A.D. \& Norry, M.J. (eds.) Magmatism in the Ocean Basins, Geological Society Special Publication 42, 313-345.

Suyehiro, K., Takahashi, N., Arile, Y., Yokoi, Y., Hino, R., Shinohara, M., KanazaWA, T., Hirata, N., TokuYama, H. \& Taira, A. 1996. Continental crust, 
crustal underplating, and low-Q upper mantle beneath an oceanic island arc. Science, 272, 390-392.

SWINDEN, H.S., JenNER, G.A. \& SzYBINSKI, Z.A. 1997. Magmatic and tectonic evolution of the Cambrian-Ordovician Laurentian margin of Iapetus: Geochemical and isotopic constraints from the Notre Dame subzone, Newfoundland, in Sinha, K., Whalen, J.B., and Hogan, J.P., eds., The Nature of Magmatism in the Appalachian Orogen: Geological Society of America Memoir 191, 337-365.

TAYLOR, S.R. 1967. The origin and growth of continents. Tectonophysics, 4, 17-34.

TAYLOR, S.R. \& MCLEnNAN, S.M. 1985. The continental crust: its composition and evolution. Blackwell, Oxford, $312 \mathrm{pp}$.

TucKer, R.D. \& MCKerrow, W.S. 1995. Early Paleozoic chronology: a review in the light of new $\mathrm{U}-\mathrm{Pb}$ zircon ages from Newfoundland and Britain. Canadian Journal of Earth Sciences, 32, 368-379.

van Staal, C.R., Dewey, J.F., MacNiocaill, C. \& McKerrow, W.S. 1998. The Cambrian-Silurian tectonic evolution of the northern Appalachians and British Caledonides: history of a complex, west and southwest Pacific-type segment of Iapetus. In: Blundell, D. J. \& ScotT, A. C., (eds), Lyell: the Past is the Key to the Present, Geological Society, London, Special Publication, 143, p. 198-242.

Van Staal, C.R., Whalen, J.B., McNicoll, V.J., Pehrsson, S., Lissenberg, C.J., Zagorevski, A., van Breemen, O. \& Jenner, G.A. 2007. The Notre Dame arc and the Taconic orogeny in Newfoundland, in Hatcher, R.D., Jr., Carlson, M.P., McBride, J.H., and Martínez Catalán, J.R., eds., 4-D Framework of Continental Crust: Geological Society of America Memoir, 200, p. 511-552.

WALDRON, J.W.F. \& VAN STAAL, C.R. 2001. Taconian orogeny and the accretion of the Dashwoods block: A peri-Laurentian microcontinent in the Iapetus Ocean. Geology, 29, 811-814.

Whalen, J.B., Jenner, G.A., Longstaffe, F.J., Gariepy, C. \& Fryer, B.J. 1997. Implications of granitoid geochemical and isotopic $(\mathrm{Nd}, \mathrm{O}, \mathrm{Pb})$ data from the Cambrian-Ordovician Notre Dame arc for the evolution of the Central Mobile belt, Newfoundland Appalachians. Geological Society of America Memoir, 191, 367395.

Draut et al. page 27 of 27 